\title{
Japan Under the DPJ: The Paradox of Political Change Without Policy Change
}

\author{
Phillip Y. Lipscy and Ethan Scheiner
}

In 2009, the Democratic Party of Japan (DPJ) brought an end to the long reign of the Liberal Democratic Party (LDP). However, despite high expectations, this politically transformative event has not unleashed significant policy change in Japan. We highlight five electoral factors that have acted as important constraints on policy change under DPJ rule. First, majoritarian electoral rules have led to a convergence in the policy positions of the two major political parties. Second, as the parties' policy positions have become more similar, voters have increasingly cast ballots based on "valence" (i.e., nonpolicy) evaluations. Third, large national vote swings have limited the tenure of young, inexperienced candidates who might otherwise serve as the instigators of reform. Fourth, Japan's electoral rules permit inconsistency across policy positions within parties and discourage greater policy coherence. Fifth, the continuing influence of rural regions has limited the scope of policy reform under the DPJ. KeYwORDs: electoral systems, Japan, policy change, party realignment, party alternation in power, reform, Liberal Democratic Party (LDP), Democratic Party of Japan (DPJ)

DURING THE PERIOD 2005-2009, JAPAN EXPERIENCED THE COUNTRY'S most significant political transformation since the formation of the Liberal Democratic Party (LDP) in 1955. In 2005, the LDP celebrated fifty years of nearly uninterrupted rule with one of its most successful elections ever but soon found itself in dramatic decline. Most notably, the Japanese elections of 2007 and 2009 saw the collapse of the LDP, and the opposition Democratic Party of Japan (DPJ) gained control of both houses of parliament (Diet). The 2007 House of Councillors election gave a DPJ-led coalition a bare majority of the 242 seats in the body, and the DPJ claimed 308 out of the 480 seats in the 2009 House of Representatives election. The elections appeared to mark the consolidation of a 
new era of genuine competitive electoral politics in Japan, potentially leading to a stable two-party system.

The DPJ had campaigned on a platform of change, and many observers of Japanese politics, including the popular press, heralded the party's triumph in 2009 as a major turning point. ${ }^{1}$ The DPJ sought to revolutionize Japanese policymaking and diminish the authority of the government bureaucracy in favor of a greater role for elected politicians and a cabinet-led system of governance (Green 2010). The DPJ victory raised the possibility of a "regime change" that would include not only a shift in the party in power, but also a new socioeconomic coalition undergirding the government and a change in the public policy profile of Japan (Pempel 2010). Indeed, among other things, the DPJ promised to curtail bureaucratic authority, enact generous new programs such as a child allowance and elimination of highway tolls, reduce fiscal waste, and pursue a foreign policy that is more independent of the United States.

In fact, since the early 1990s, academic work on Japanese politics has anticipated the rise of two-party competition and significant policy change (see especially Ramseyer and Rosenbluth 1993)—both emerging as a result of new electoral rules that were first used in Japan in 1996. Much of the recent work on Japanese politics has applied insights from the formal and cross-national literature on electoral rules and their impact on party politics (Duverger 1954; Downs 1957; Rae 1971; Lijphart 1994; Cox 1997; Bawn and Thies 2003). In 1994, Japan replaced its single nontransferable vote (SNTV) electoral system with a mixed-member system that places greater emphasis on plurality voting in single-member districts (SMDs). The previous system encouraged particularism over broad, public appeal, and consequent LDP one-party dominance (Rosenbluth 1989; Sakakibara 1991; Ramseyer and Rosenbluth 1993; McCubbins and Rosenbluth 1995; Scheiner 2006). The new electoral rules, especially the single-member districts, created strong incentives to target the median voter through broad, programmatic appeal (Downs 1957; Cox, Rosenbluth, and Thies 1999; Hirano 2006; Rosenbluth et al. 2009; Rosenbluth and Thies 2010). According to most analyses, these electoral incentives encourage two-party competition with partisan differentiation along a left-right continuum - a break from traditional patterns in Japanese politics, where, with the exception of foreign policy, such a cleavage has been difficult to identify (Proksch, Slapin, and Thies 2011; Rosenbluth and Thies 2010).

Indeed, the new electoral system worked as expected in promoting a (roughly) two-party system and an increase in issue-oriented politics. As Kenneth McElwain and Ethan Scheiner illustrate in their articles in 
this issue, the coming to power of the DPJ is a stark illustration of the new electoral calculus in Japan, which has increasingly consolidated toward two-party competition. There has been a marked decline in particularistic spending in recent decades in favor of programmatic policies such as social spending and education (Noble 2010). Furthermore, as Scheiner highlights in his article, there has been an increase in recent years in the number of candidates who use specific policy appeals to reach out to voters. In 2009 , the DPJ campaigned with an electoral strategy that emphasized policies with broad appeal to urban voters, such as a generous child allowance, elimination of transportation taxes, and reduction of wasteful public works projects.

Given these momentous changes in Japanese electoral politics and the public displeasure with the LDP's lack of responsiveness to the significant economic and sociodemographic problems facing Japan, one would think that party alternation in power would have promoted major policy change-but, in fact, once in power, the DPJ did not produce much legislation that was meaningfully different from that of the LDP. To be sure, with the high hopes surrounding it, the DPJ was bound to disappoint, but what is striking about the initial years of the DPJ government is how little policy changed. Aside from a few legislative victories, such as the government-provided child allowance, which was scaled back and eventually repealed, the DPJ did not implement policies significantly different from those of its predecessor. The government appeared rudderless and internally divided, repeatedly modifying or abandoning core campaign pledges that were seemingly at the heart of the party's electoral strategy.

In addition, the DPJ has, counterintuitively, assiduously courted the rural vote-hardly the national median - which, according to conventional accounts of campaigning under first-past-the-post electoral rules, should have been increasingly marginalized. In the 2007 election for the House of Councillors, the DPJ won big in rural districts by promising a restoration in rural subsidies, in effect partially swapping policy platforms with the LDP for short-term electoral gain. Similarly, the DPJ has provided budgetary support for (especially rural) localities. As Frances Rosenbluth and Michael Thies $(2010,119)$ point out, the DPJ's overture to the countryside - in essence, trying to "leapfrog" the LDP's own ruralbased policies to appeal even more to rural areas-is highly unusual in the context of policy-based, two-party competition.

In short, the coming to power of the DPJ, a politically transformative event, was not accompanied by similarly transformative policy outcomes. How can we explain this apparent paradox? This question is 
important for more than just academic reasons. The DPJ was unable to address major policy issues facing Japan and, as a result, quickly lost the support of the Japanese public. Rapid public disillusionment with the DPJ was underscored by the results of the 2010 Japanese upper house election, in which the LDP won seven more seats than DPJ and thus returned control over the upper house to the longtime ruling party and its partners. ${ }^{2}$ The poll breathed new life into the LDP that, along with new conservative groupings, stepped back from the brink of self-destruction and further constrained the DPJ's ability to pass legislation.

\section{The Sources of Policy Stability Under the DPJ}

In this special issue, we highlight the importance of structural electoral factors that have contributed to the apparent paradox of political change without policy change in Japan.

Certainly, there are several factors that have constrained governance under the DPJ. One temporary, but nonetheless important, source of early paralysis under the DPJ government was ironically a core element of the party's campaign manifesto-to curtail the influence and power of Japan's elite bureaucracy. The DPJ came to power promising to exert "political leadership," reducing the role of the bureaucracy in decisionmaking processes. However, as a practical matter, trying to marginalize the bureaucracy threw the policymaking process into chaos, as bureaucrats resisted and politicians struggled to handle the enormous demands placed on their time. ${ }^{3}$ In foreign policy, despite considerable domestic dissatisfaction with US bases in Okinawa, Japan is ever more dependent on the United States as it faces an erratic North Korea and increasingly assertive and powerful China. ${ }^{4}$ This dependence imposes an international structural constraint that makes a sharp break from past foreign policy patterns difficult even for a new administration. Japan's anemic economic growth, rapidly aging population, and high levels of preexisting debt limit the scope for new, expensive initiatives and compels every government to consider some form of budgetary austerity; there is less room for popular handouts and greater need for unpopular cutbacks. ${ }^{5}$ In addition, the March 11, 2011, Great Tohoku Earthquake/tsunami/nuclear accident further hampered policy change and led to a wholesale abandonment of policies - such as the child allowance and the reduction of highway tolls - that had been implemented on a limited or experimental basis. Reconstruction will further exacerbate Japan's public debt position, and the fallout from the Fukushima nuclear plant disaster will reduce the scope for flexibility in energy policy. 
Nevertheless, compared with the factors listed above, which are widely recognized and cited by existing scholarship, the electoral constraints on policymaking have received scant attention. As we discussed earlier, the transformation of Japanese electoral politics is real but has not seen significant policy change go hand-in-hand with party alternation in power. As Scheiner's article demonstrates, the new electoral system has promoted district-level two-party competition, and as McElwain highlights in his contribution, the locus of electoral attention has shifted from the local/district level to a nationalized party system. The DPJ and LDP are now national parties, and Japan has a robust twoparty system. However, what is puzzling is why Japan's two-party system has not developed a cleavage along programmatic lines observed in other majoritarian political systems such as the United States or United Kingdom. In particular, why have the LDP and DPJ failed to clearly differentiate themselves according to a left-right continuum on domestic economic policy as the Democratic and Republican parties do in the United States? We highlight five electoral factors that have constrained significant policy change under party alternation and DPJ control of the government.

First, the lack of a major policy cleavage is actually largely consistent with the predictions of the literature on party competition under majoritarian electoral rules; as both parties attempt to court the median voter, policy positions have converged and dramatic policy shifts have become less likely (Downs 1957). By the time the DPJ came to power in 2009, the LDP had made significant adjustments to its traditional political strategy, particularly under Prime Minister Koizumi (Reed, McElwain, and Shimizu 2009). Under the banner of reform with no sanctuary, Koizumi centralized power in the Cabinet Office and campaigned vigorously for postal privatization and reform of fiscal redistribution mechanisms that had sustained LDP dominance for much of the postwar period. Indeed, as Scheiner highlights in his article, candidates from both the LDP and DPJ have converged toward one another in their policy appeals. In addition, as Phillip Lipscy discusses in his contribution, significant policy reforms (such as a shift to greater energy efficiency) involve imposing diffuse costs on the general public - something that is risky for both parties to initiate when competing in a volatile, two-party system where the median voter would bear the brunt of such costs.

Second, as Scheiner (this issue) highlights-and as expected by Anthony Downs $(1957,44,136)$-as the LDP's and DPJ's policy positions have become more similar, voters have increasingly cast ballots based on "valence" (i.e., nonpolicy) evaluations of the parties. Previously, vot- 
ers had given great weight to the political experience of candidates, but as the party system became nationalized, elections became decided by voters' images of the LDP and DPJ as agents of change (Reed, Scheiner, and Thies 2012). With elections increasingly determined by party image, but not differences in policy, it becomes less likely that a new party in power will have a mandate to implement significant, specific change. For example, as Alisa Gaunder highlights in her article, rather than proposing and implementing meaningful policies favoring women, both parties have turned to "female assassin" candidates to demonstrate their reform bona fides and therefore appeal to fickle popular sentiment.

Third, the volatility of Japan's nationalized, two-party elections helps, at least in small part, to explain some of the difficulty parties in Japan now face as initiators of significant policy change. The large national vote swings that accompany elections in Japan now limit the tenure of all politicians, but especially young, inexperienced candidates who might otherwise serve as the instigators of reform. As Gaunder points out, the prospects for new policies favoring women have been limited by the high turnover of young, female candidates in both parties.

Fourth, much of the reason that the DPJ's control of the government has not led to greater policy reform is that Japan's electoral rules permit inconsistency across policy positions within parties - and the electoral incentives of the rules can make it difficult to create greater party policy coherence. With 300 plurality districts across the country, individual politicians within a party need not all conform to identical policy positions. And both major parties in Japan are divided across their different districts: the LDP among reformers associated with former prime minister Koizumi and more conservative "rebels," and the DPJ between those supporting and opposing Ichiro Ozawa's traditionalist approach. In theory, party realignment might occur whereby large numbers of sitting politicians create new parties or switch to existing alternatives to create greater policy coherence within parties. However, as Scheiner (this issue) indicates, (1) first-past-the-post rules make it extremely difficult for new parties to develop a foothold, and (2) the DPJ politicians who appear to have the strongest policy reasons to leave the party (they have the least in common with others in their party) also face a tough electoral environment in their districts; defecting and losing the support of the DPJ would probably lead them to defeat. With no significant party realignment to address such intraparty divisions, Japan's parties have struggled to implement bold, new policies. As Lipscy points out, intraparty divisions between reformists and traditionalist politicians forced the DPJ to scale down its transportation reform proposals dramatically once in office. In summer 
2009 Ozawa did in fact bolt from the party, but despite his seemingly huge base of support within the party, in the end only about three dozen members of the House of Representatives left with him. Such moves may ultimately lead to a "purer" DPJ that can differentiate itself more starkly from the LDP, but it is noteworthy that Ozawa's defection was in large part in reponse to the DPJ's efforts to increase the consumption tax-a proposal that the LDP largely supported. Nevertheless, party defectionseven if running counter to most electoral incentives created by Japan's system-remain the greatest hope for genuine change among many Japanese political observers and politicians (Sato 2011).

Fifth, the continuing influence of rural regions has limited the scope of policy reform under the DPJ. The decline of rural voters compared to the heyday of LDP rule is unmistakable, a point McElwain emphasizes in his analysis of electoral developments in this issue. Rural subsidies have been cut substantially over the past two decades (Noble 2010; Rosenbluth and Thies 2010). However, rural areas still exercise outsized influence over Japanese politics (Reed, Scheiner, and Thies 2012), limiting the scope for dramatic departures from extant policies. This continuity can be attributed to several factors. Although the electoral overrepresentation of rural interests has diminished considerably, rural areas still constitute the principal support base of the LDP and a significant share of the DPJ's lower house representation. The DPJ achieved considerable success in the 2004 and 2007 upper house and 2009 lower house elections by following Ozawa's strategy of appealing to rural voters. The LDP turned the tide in the 2010 upper house election primarily by winning back rural single-member districts. Notably, the rules governing elections to the upper house in Japan place greater emphasis on rural areas compared to the lower house, and the nearly coequal status of the two houses makes it imperative to secure double majorities. Both parties must therefore craft political platforms that appeal not only to urban floating voters but also to local, rural constituencies. In effect, despite their declining overall representation, rural residents have acted as swing voters in recent elections.

Moreover, as Kay Shimizu (this issue) argues, redistricting and local autonomy have cut against electoral incentives provided by the rules used to elect politicians to the House of Representatives by increasing the leverage of especially local rural politicians vis-à-vis central politicians. Finally, although Japan's new electoral rules have placed greater emphasis on urban voters, rural voters tend to turn out more reliably. Because overall turnout itself is volatile, cultivating the rural vote has remained 
an important electoral strategy for both political parties as an insurance policy against low-turnout elections.

\section{The Articles}

The five articles in this special issue assess the impact of electoral constraints on DPJ policymaking from several different perspectives and highlight the importance of the five factors identified above.

Kenneth McElwain examines how, since the advent of the new electoral system in the mid-1990s, the locus of electoral attention has shifted from the local/district level to a nationalized party system. For decades, much of the LDP's success was a result of the fact that elections in Japan tended to be highly decentralized: each district remained largely distinct from all others, as campaigns in each tended to focus on local conditions and the individual candidates running for office. McElwain demonstrates how, in recent years, elections in Japan have become "nationalized," with national parties gaining importance and the vote in each district likely to swing in line with the vote in other districts across the country. This nationalization has created strong incentives for politicians to design campaign platforms that appeal to urban, floating voters. As a result, one might expect a more policy-oriented party system in which party alternation leads to significant policy change.

Ethan Scheiner highlights the ways in which the new electoral system has constrained greater policy differentiation between the DPJ and LDP. He illustrates how LDP and DPJ candidates in each district tend to promote policies that are similar to one another, thus leading voters simply to support the candidate from the national party that they deem most likely to implement reform. Moreover, the first-past-the-post rules have helped the parties remain internally divided, and the newfound stability of the party system also makes it less likely that there will be major partisan realignment to create parties that are based on more consistent ideology. In short, Japan's electoral rules have encouraged the development of what is essentially a two-party system, but one in which elections are not about fundamental policy differences between parties and, therefore, one in which party alternation in power need not produce sharp policy change.

Kay Shimizu analyzes a critical—but largely unnoticed—institutional change that has altered politics dramatically since 2003. LDP dominance had long been buttressed by the existence of a large number of municipallevel politicians who worked on behalf of national LDP politicians who sought reelection. Shimizu demonstrates that in recent years, municipal 
mergers have reduced the number of such politicians, which in turn undercut much of the foundation of LDP success. At the same time, at the local level, the DPJ did not benefit directly from the new arrangements. Instead, local governments and politicians have become more independent from both major parties. As a result, at a time of increasing numbers of floating voters, neither the LDP nor DPJ can depend on support from its local base across the country. To succeed, both parties must pay attention to the needs of the increasingly independent-and very often, rural-localities. This factor cuts against electoral incentives to target urban voters, pulling each political party in contradictory directions.

Phillip Lipscy examines how these electoral constraints affected the DPJ's core campaign promises in the transportation sector. Under traditional LDP rule, Japan had pursued what Lipscy calls "efficiency clientelism." Policies were designed or co-opted to serve a dual purpose: encourage energy efficiency by raising costs diffusely for the general public, while also generating pork for redistribution to key LDP constituents. As McElwain outlines, electoral reform has transformed Japan into a volatile, two-party system that emphasizes broad public appeal over narrow redistribution. Under this new system, it has become difficult to sustain policies that impose diffuse costs on the general public, which is an essential feature of $\mathrm{CO}_{2}$ reduction measures in the transportation sector. Hence, the DPJ's pledges to reduce transportation costs, which were designed to appeal to the broad electorate, ran up against the prospect of massive increases in greenhouse gas emissions. In addition, consistent with Scheiner's analysis, transportation policymaking has been characterized by internal conflicts within both the LDP and DPJ-traditionalist politicians have often succeeded in reshaping ambitious proposals by reformists to the benefit of their political supporters. The net result has been the de facto nonimplementation of what was a core platform of the DPJ's electoral strategy.

Alisa Gaunder examines the status of women in politics under the DPJ. Here again, the story is one of striking continuity between the LDP and DPJ. In many ways, there have been increasing incentives in Japan for the promotion of women-especially as elections have become nationalized, as campaigns focus more on independent floating voters, and as valence considerations take on greater weight. Not surprisingly, therefore, the DPJ has placed priority on offering greater opportunities to women within its ranks - thus creating an image of a change-oriented party-and the party has formal rules and programs to encourage the recruitment of female candidates. However, the predominant strategy of the party under the current electoral system has been broadly similar to that of the LDP- 
to use young, inexperienced women as contrast candidates in swing elections against established, male incumbents. With the nationalization of two-party competition, Japanese elections in recent years have come to see massive vote and seat swings, so that female candidates across both parties, although increasing in number, frequently lose in subsequent elections and rarely ascend to leadership positions. As a result, there have been few powerful female leaders in either major party, and few male leaders appear interested in promoting pro-women policy positions. In turn, there has been little progress on such issues under the DPJ.

Taken as a whole, these articles highlight systematic patterns that have emerged through the recent period of major change in Japan. Elections have become fluid, but not in a haphazard way. In contrast to the past, elections are now meaningful contests between large parties, and shifts in the public mood have the power to lead to alternation in power. However, this electoral shift has not led to meaningful differentiation over policies. Despite a platform for ambitious change, the DPJ in power has come to closely resemble the LDP. Both major parties in Japan face stringent, common constraints on policymaking, which lead them to adhere to a relatively similar set of policies. These policies are oftentimes incoherent to the general public and unpopular, a factor that exacerbates popular disaffection with both major political parties. As a result, Japan's new political system has become characterized by party change without concomitant policy change.

\section{Notes}

Thanks to Steph Haggard and two anonymous reviewers for helpful comments on earlier drafts.

1. See, for example, Iinuma (2009), as well as the extensive list of media quotes in Rosenbluth and Thies $(2010,186)$.

2. In reality, the DPJ won the most votes in the election, but vagaries of the upper house's districting system provided a huge seat advantage to the LDP.

3. Harris (2011) provides an excellent overview.

4. Sneider (2011) discusses the DPJ's Asianist orientation and the challenges it confronted once in office.

5. For a discussion of the politics of budgetary austerity and demographic change in Japan, see de Koning and Lipscy (2011).

\section{References}

Bawn, Kathleen, and Michael F. Thies. 2003. "A Comparative Theory of Electoral Incentives: Representing the Unorganized Under PR, Plurality and Mixedmember Electoral Systems." Journal of Theoretical Politics 15, 1: 5-32.

Cox, Gary. 1997. Making Votes Count. New York: Cambridge University Press. 
Cox, Gary, Frances McCall Rosenbluth, and Michael Thies. 1999. "Electoral Reform and the Fate of Factions: The Case of Japan's LDP." British Journal of Political Science 29: 33-56.

de Koning, Philippe, and Phillip Y. Lipscy. 2011. "Resilience or Retrenchment? Japanese Security in the Era of Fiscal Austerity." Working Paper, Stanford University.

Downs, Anthony. 1957. An Economic Theory of Democracy. New York: Harper and Row.

Duverger, Maurice. 1954. Political Parties. New York: Wiley.

Green, Michael. 2010. “Japan's Confused Revolution.” Washington Quarterly 33, 1: 3-19.

Harris, Tobias. 2011. "Administrative Reform Under the DPJ: Progress and Problems in Building a Westminster System." Paper presented at the Political Change in Japan Conference, Stanford University.

Hirano, Shigeo. 2006. "Electoral Systems, Hometowns, and Favored Minorities: Evidence from Japan's Electoral Reforms.” World Politics 59, 1.

Iinuma, Yoshisuke. 2009. "Koizumi Says DPJ Is Party of Reform; Hatoyama: I'm No Puppet." Oriental Economist 77, 10: 6-7.

Lijphart, Arend. 1994. Electoral Systems and Party Systems. New York: Oxford University Press.

McCubbins, Mathew, and Frances McCall Rosenbluth. 1995. "Party Provision for Personal Politics: Dividing the Vote in Japan." In Structure and Policy in Japan and the United States, ed. P. F. Cowhey and M. McCubbins. Cambridge: Cambridge University Press.

Mulgan, Aurelia George. 2012. “A New Ozawa Party for Japan?” www.eastasia forum.org/2012/05/12/a-new-ozawa-party-for-japan.

Noble, Gregory W. 2010. "The Decline of Particularism in Japanese Politics." Journal of East Asian Studies 10, 2: 239-273.

Pempel, T. J. 2010. "Between Pork and Productivity: The Collapse of the Liberal Democratic Party.” Journal of Japanese Studies 36: 227-254.

Proksch, Sven-Oliver, Jonathan B. Slapin, and Michael Thies. 2011. "Party System Dynamics in Post-war Japan: A Quantitative Content Analysis of Electoral Pledges." Electoral Studies 30, 1: 114-124.

Rae, Douglas. 1971. The Political Consequences of Electoral Laws. New Haven: Yale University Press.

Ramseyer, Mark, and Frances McCall Rosenbluth. 1993. Japan's Political Marketplace. Cambridge: Harvard University Press.

Reed, Steven R., Kenneth Mori McElwain, and Kay Shimizu. 2009. Political Change in Japan: Electoral Behavior, Party Realignment, and the Koizumi Reforms. Stanford: Shorenstein APARC.

Reed, Steven R., Ethan Scheiner, and Michael F. Thies. 2012. "The End of LDP Dominance and the Rise of Party-oriented Politics in Japan.” Journal of Japanese Studies 38, 2: 353-375.

Rosenbluth, Frances McCall. 1989. Financial Politics in Contemporary Japan. Ithaca: Cornell University Press.

Rosenbluth, Frances McCall, Mathew McCubbins, Jun Saito, and Kyohei Yamada. 2009. "Median Districts and District Medians: Electoral Adaptation 
to Majoritarian Politics in Post-1994 Japan.” Paper presented at the annual meeting of the American Political Science Association, Toronto.

Rosenbluth, Frances McCall, and Michael F. Thies. 2010. Japan Transformed: Political Change and Economic Restructuring. Princeton: Princeton University Press.

Sakakibara, Eisuke. 1991. "The Japanese Politico-Economic System and the Public Sector." In Parallel Politics: Economic Policymaking in the United States and Japan, ed. S. Kernell. Washington DC: Brookings Institution Press.

Sato, Akira. 2011. "Big Bang: Conservative Merger Expected from Political Supernova." Asahi Shimbun Weekly Aera, March 2.

Scheiner, Ethan. 2006. Democracy Without Competition in Japan: Opposition Failure in a One-party Dominant State. Cambridge: Cambridge University Press.

Sneider, Daniel. 2011. "The New Asianism: Japanese Foreign Policy Under the Democratic Party of Japan.” Asia Policy 12 (July). 